\title{
Chronic CSF leak causing syringomyelia and pseudo-Arnold-Chiari malformation
}

Figure Sagittal T2 MRI
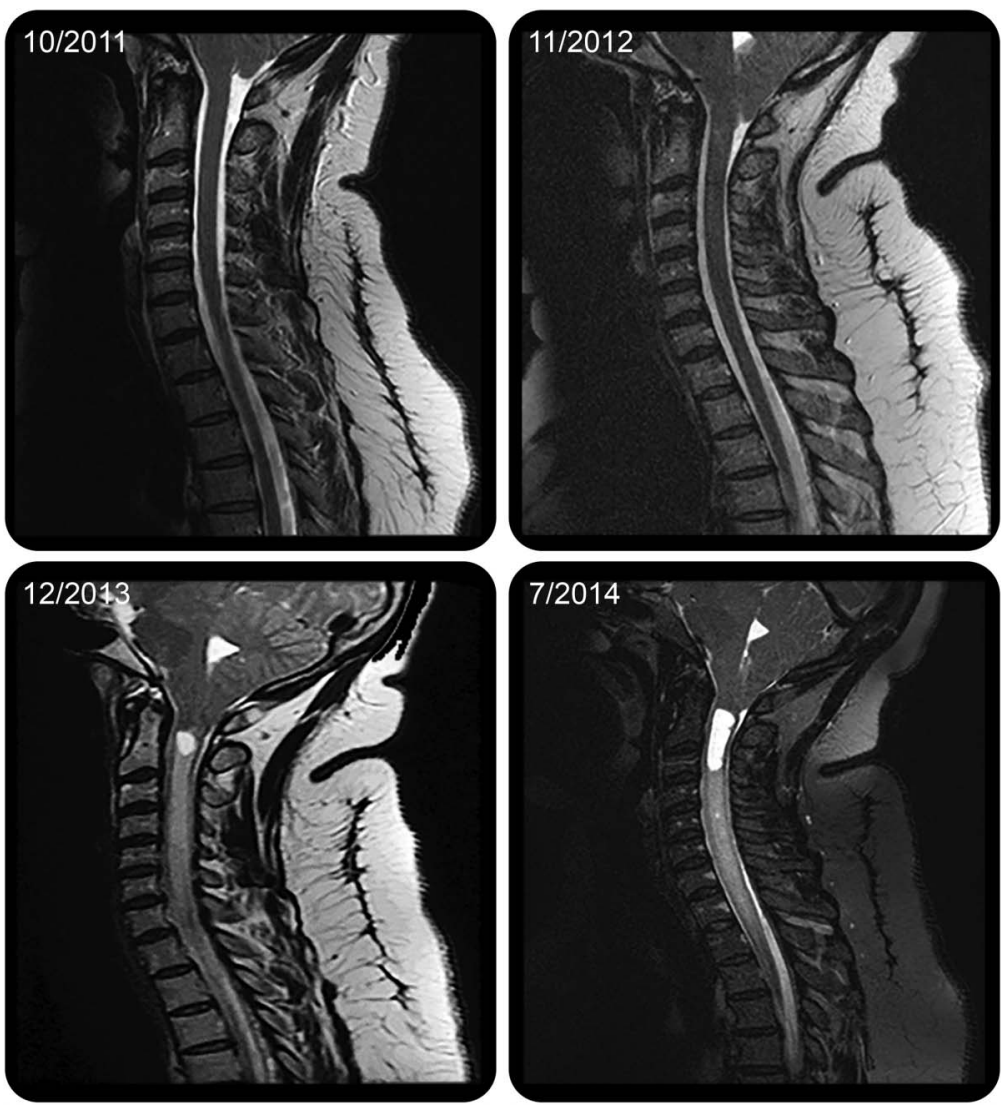

Images demonstrate progressive cerebellar tonsillar descent and development of syrinx within the intramedullary cavity from $\mathrm{C} 1$ to $\mathrm{C} 3$, with T2 signal suggestive of intramedullary hydrostatic edema extending caudally to T4-5.

A 45-year-old woman developed orthostatic headaches after lifting weights. A CT myelogram localized a CSF leak at T5-T7. Multiple blood patches provided only transient relief. Over 5 years, the patient developed paresthesias, worsened headaches, and decreased hand coordination. MRI showed progressive cerebellar tonsillar descent and hydrosyringomyelia (figure). Repeat myelography was unrevealing, but subsequent multilevel epidural blood patches with fibrin glue led to headache resolution. Cerebellar tonsillar descent and hydrosyringomyelia can occur in chronic spontaneous CSF leaks. ${ }^{1}$ A CSF leak should be considered in patients with orthostatic headache and presumed Chiari malformation.

Ryan M. Smith, DO, Ivan Garza, MD, Carrie E. Robertson, MD

From the Mayo Clinic, Rochester, MN.

Study funding: No targeted funding reported.

Disclosure: R. Smith reports no disclosures relevant to the manuscript. I. Garza receives royalties from UpToDate Inc. C. Robertson receives royalties from UpToDate Inc. Go to Neurology.org for full disclosures.

Correspondence to Dr. Robertson: robertson.carrie@mayo.edu

1. Samii C, Möbius E, Weber W, Heienbrok HW, Berlit P. Pseudo Chiari type I malformation secondary to cerebrospinal fluid leakage. J Neurol 1999;246:162-164. 


\section{Neurology}

\section{Chronic CSF leak causing syringomyelia and pseudo-Arnold-Chiari malformation}

Ryan M. Smith, Ivan Garza and Carrie E. Robertson Neurology 2015;85;1994

DOI 10.1212/WNL.0000000000002178

This information is current as of November 30, 2015

\begin{tabular}{|c|c|}
\hline $\begin{array}{l}\text { Updated Information \& } \\
\text { Services }\end{array}$ & $\begin{array}{l}\text { including high resolution figures, can be found at: } \\
\text { http://n.neurology.org/content/85/22/1994.full }\end{array}$ \\
\hline References & $\begin{array}{l}\text { This article cites } 1 \text { articles, } 0 \text { of which you can access for free at: } \\
\text { http://n.neurology.org/content/85/22/1994. full\#ref-list-1 }\end{array}$ \\
\hline Citations & $\begin{array}{l}\text { This article has been cited by } 2 \text { HighWire-hosted articles: } \\
\text { http://n.neurology.org/content/85/22/1994.full\#\#therarticles }\end{array}$ \\
\hline Subspecialty Collections & $\begin{array}{l}\text { This article, along with others on similar topics, appears in the } \\
\text { following collection(s): } \\
\text { MRI } \\
\text { http://n.neurology.org/cgi/collection/mri }\end{array}$ \\
\hline Permissions \& Licensing & $\begin{array}{l}\text { Information about reproducing this article in parts (figures,tables) or in } \\
\text { its entirety can be found online at: } \\
\text { http://www.neurology.org/about/about_the_journal\#permissions }\end{array}$ \\
\hline Reprints & $\begin{array}{l}\text { Information about ordering reprints can be found online: } \\
\text { http://n.neurology.org/subscribers/advertise }\end{array}$ \\
\hline
\end{tabular}

Neurology ${ }^{\circledR}$ is the official journal of the American Academy of Neurology. Published continuously since 1951, it is now a weekly with 48 issues per year. Copyright () 2015 American Academy of Neurology. All rights reserved. Print ISSN: 0028-3878. Online ISSN: 1526-632X.

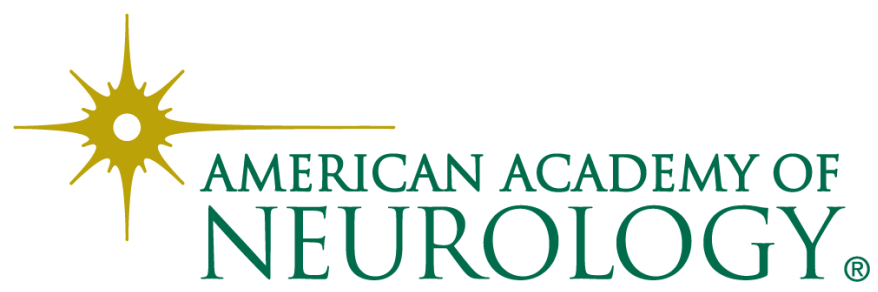

